Article

\title{
Do Indigenous Street Trees Promote More Biodiversity than Alien Ones? Evidence Using Mistletoes and Birds in South Africa
}

\author{
Charlie Shackleton \\ Department of Environmental Science, Rhodes University, Grahamstown 6140, South Africa; \\ c.shackleton@ru.ac.za; Tel.: +27-46-603-7001 \\ Academic Editors: Francisco Escobedo, Stephen John Livesley and Justin Morgenroth \\ Received: 19 April 2016; Accepted: 29 June 2016; Published: 13 July 2016
}

\begin{abstract}
Trees in urban landscapes provide a range of ecosystem services, including habitat, refugia, food, and corridors for other fauna and flora. However, there is some debate whether the richness and abundance of other biodiversity supported is influenced by the provenance of trees, i.e., native or non-native. This study assessed the presence of mistletoes and birds (and nests) in 1261 street trees. There were marked differences between native and non-native street trees, with the former having a significantly higher prevalence of birds (and nests) and supporting more species and in greater densities, whilst the latter supported a higher prevalence of mistletoes. Additionally, for birds, the proximity to green space, tree size and species were also important, whilst for mistletoes, the proximity to green space, slope aspect, and tree species were significant. Preference ratios indicated that some tree species had a higher than random occurrence of birds or mistletoes, whilst others had a low abundance. The indigenous tree species, Acacia karroo Hayne was the only reasonably abundant street tree species that was important for birds, nests, and mistletoes. At the street scale, there was a positive relationship between street tree species richness and bird species richness. These results emphasise the importance of selecting appropriate tree species if biodiversity conservation is a core outcome.
\end{abstract}

Keywords: biodiversity; connectivity; preference ratio; street trees; tree size; urban

\section{Introduction}

Trees in public urban spaces provide a variety of provisioning, regulating, cultural, and supporting ecosystem services to urban residents and necessary ecological processes [1,2]. Consequently, there is a growing emphasis on the greening of urban environments to maximise the provision of such ecosystem services [3]. Street trees are a particularly important component of urban greening because (i) they are located throughout the urban matrix; (ii) although streets are narrow, their combined area is often much larger than that of formal parks and green spaces; and (iii) a considerable proportion of the time that urban residents spend outdoors is spent on the streets, according to Todorova et al. [4] a considerable proportion of the time that urban residents spend out of doors in spent on the streets. Thus, ensuring that the streets are attractive, safe, and as functional as possible for urban residents is an import consideration for city planners and parks officials [5].

Besides all the benefits that urban residents receive from street and other urban trees, they also provide supporting services in the form of food, habitat, shelter, refugia, nesting materials, and breeding sites for many other species occurring in towns and cities. For example, the early work of Tzilkowsjki et al. [6] revealed that one-third of street trees had birds in them and that the prevalence differed markedly between different tree species, whilst Kubista \& Bruckner [7] reported that urban trees provided $50 \%$ of the roost sites for several species of bats. 
As a means of promoting the benefits of trees as habitat and food for other biodiversity, it is often stated that indigenous (native) trees should be encouraged above alien (exotic/non-native) species, because the services that they provide are already part of the local ecology, and other native species will have co-adapted with them [8-11]. These works present several examples of local biodiversity plans or urban ward authorities specifically regulating for native species over alien ones. Thus, from a biodiversity conservation perspective, indigenous trees are often seen as more beneficial for other native species than are alien ones. However, there has been limited empirical evaluation of this claim in urban settings $[8,11]$. This is particularly so for street trees.

Carthew et al. [12] recorded the presence of hollows in trees in six parks in Adelaide, Australia, and their occupation by brushtail possums (Trichosurus vulpecula). They reported that only one-third of possum dens were in indigenous trees, and the statistical analysis indicated that indigenous tree species were less likely to be used for den sites than the most common alien tree species. Blanchon et al. [13] found that an urban forest dominated by alien woody plants had 50\% more species of ground beetles than a smaller, nearby urban forest dominated by indigenous plants. In contrast, bird and butterfly species richness was more diverse within and between green patches in Singapore dominated by native vegetation relative to those dominated by non-native species [14]. Gariola et al. [15] found that the alien tree species Melia azedarach L. was a common host for mistletoes in urban parks in Durban (South Africa).

Whilst such comparisons are valuable, there are confounding variables-most notably, the size of the forest or park studied and the structural diversity of the broader site. Two studies with birds reduced these confounding factors to some degree by examining visitation rates of native birds to individual trees. French et al. [16] and Gray and van Heezik [17] both compared visitation rates of birds to selected indigenous and alien tree species, the former in Australia and the latter in New Zealand. French et al. [16] found that, whilst birds visited all four tree/shrub species, the rate of visitation was significantly higher for the indigenous ones. The results of Gray and van Heezik [17], who monitored six species, were more equivocal and varied with season, but they concluded that exotic trees can sustain native birds. The same cannot be said for epiphytes, as there is a scarcity of literature on epiphytes in urban trees. The commentary of Johnston et al. [10] and the recent review by Chalker-Scott [11] also concluded that alien tree species can provide the same services to other biodiversity as native tree species do. However, if this is to be situated within a conservation debate, the question needs to be more nuanced, i.e., not whether exotic trees species can sustain native biodiversity, but rather can they sustain more, either in species richness or abundance. If the exotic species were removed, would it result in a loss of certain native biodiversity that was dependent upon them? If yes, would it be at levels about which managers and conservationists should be concerned? Dickie et al. [18] describe several examples of where removal of alien tree species was resisted or halted due to their perceived importance in providing food or habitat to charismatic or endangered native fauna, but can the same food or habitat be provided by indigenous species?

From the above, it is apparent that current debates on the relative merits of native or alien trees in supporting other indigenous biodiversity are fraught with conflicting positions and sometimes equivocal results confounded by differences in patch size, the presence of other species in the patch, variable structure between patches, and the nature of the surrounding matrix. Using street trees as the sample unit reduces or eliminates the confounding issues. Within the context of the above, this paper reports on a study, the aim of which was to ascertain whether there is any difference in the use of native or alien street trees by other biodiversity, using street trees as the sample unit and birds and mistletoes as components of supported biodiversity.

\section{Materials and Methods}

\subsection{Study Site}

Grahamstown $\left(33^{\circ} 18^{\prime} \mathrm{S} ; 26^{\circ} 33^{\prime} \mathrm{E}\right)$ is a medium-sized town in the Eastern Cape province of South Africa, with a population of approximately 70,000 people. It is the administrative centre of the Makana local municipality. Having been founded as a military base during the colonial frontier wars of the 
early 1800s, it is now a well-known educational centre, with a university and numerous private and state schools. Grahamstown is located at an altitude of 650 m.a.s.l and has a moderate climate with an average seasonal temperature ranging from 9.8 to $23.1^{\circ} \mathrm{C}$. The hottest months are December to March, and the coldest months are June and July [19]. It receives, on average, $669 \mathrm{~mm}$ of rainfall annually [20], with bimodal peaks in October-November and again in March-April, largely as frontal rain showers. The city is situated within a region of high biodiversity as it lies in the convergence zone of four major biomes, namely, fynbos, grassland, thicket, and karoo [21].

The more affluent, western suburbs are well greened, both in terms of formal green spaces and street trees, whilst the poorer eastern suburbs are not [22,23]. The inequitable distribution is a legacy of South Africa's racially discriminatory past [22], current developmental budgets favouring basic infrastructure over environmental or what are deemed luxury concerns [24], and high rates of vandalism and livestock damage to trees in some areas [25]. Consequently, the study was restricted to the western suburbs. Mean housing density varies from $4.3 \mathrm{ha}^{-1}$ in the western suburbs to $32.3 \mathrm{ha}^{-1}$ in the newly constructed low-cost state housing areas (reserved for the indigent) in the east [22]. Kuruneri-Chitepo \& Shackleton [23] reported that approximately $60 \%$ of the street trees are not indigenous to South Africa and that the three most common species are Grevillea robusta A.Cunn, Jacaranda mimosifolia D.Don, and Brachychiton acerifolium (A.Cunn.) F. Muell., all alien species.

\subsection{Field Methods}

Eight residential suburbs were selected on the basis of their high street tree abundance [23] (namely, Currie Park, Hill 60, Kingswood, Oatlands, Oatlands North, Somerset Heights, Sunnyside, and West Hill), allowing for the full range of aspects (north-, east-, south-, and west-facing). In each suburb, all streets longer than $50 \mathrm{~m}$ and containing at least ten street trees taller than $2 \mathrm{~m}$, running parallel to the prevailing slope, were sampled. Sampling continued until 100 trees with mistletoes were recorded (a total of 38 streets). Sampling was done in early to mid-morning and again in mid to late afternoon; rainy or windy days were avoided.

Within each street, all street trees taller than $2 \mathrm{~m}$ on both sides of the road were inventoried. Since not all properties have boundary fences, it is possible that some of the sampled trees were not public street trees but planted by the property owners, but that has no effect on the objectives and results of this study. For each tree, the following information was recorded: (i) the species; (ii) the basal diameter at approximately $35 \mathrm{~cm}$ above ground level; (iii) the number and species of any mistletoes; (iv) a visual estimate of the proportion of the tree canopy occupied by mistletoes; (v) the number of bird's nests; and (vi) any birds (number and species noted) in the tree or any that flew into or out of the tree as it was approached. The bird observation time was approximately 6 min per tree, within the usual 5 or 10 min typical for bird surveys (which usually survey a much larger area, such as within a $25 \mathrm{~m}$ radius). The author's presence was unlikely to have had much effect on the birds since, being on streets, there was already a measure of human activity with pedestrians, bicycles, and vehicles. The size of each mistletoe was visually estimated as small, medium, or large, roughly corresponding to $<0.5 \mathrm{~m}$, 0.5-1.0 m, and >1.0 m diameter, respectively. If a given tree was multi-stemmed, the diameter of only the largest stem was measured. If a tree was branching at the measurement height, the diameter was measured above the branching or swelling. Sampling was done at the end of winter (August and September 2015) to optimise the visibility of mistletoes and nests, as this was the time of lowest leaf abundance on trees and when all trees were in the same phenophase to eliminate the effects of differential timing of flowers, fruiting, or seeding on bird presence. It is therefore likely that most nests observed were old, being from the previous summer. Coniferous species (a negligible proportion of street trees in Grahamstown [23]) were omitted because of their evergreen nature and, for several species, very dense canopy, which made detection of mistletoes and nests almost impossible. That period of the year was prior to the arrival of summer migratory bird species, which will have reduced the frequency of bird encounters and species richness to some extent, but does not undermine the comparative basis of the study. Any trees that could not be identified due to the absence of leaves were revisited three months later in the spring, when leaves and flowers were available. The linear distance from the mid-point along the street to the nearest public green area (formal or informal) with at least 10\% woody plant cover was measured using Google Earth images (2015). 


\subsection{Data Analyses}

Preference ratios per common tree species were determined as the percentage that a given tree species contributed to all trees infected with mistletoes to the percentage contribution of that same species to all street trees sampled. The same was done for birds and bird's nests. A preference ratio of greater than 1 signifies a rate of occurrence of mistletoes, birds, or nests in a particular tree species greater than would be expected if their presence was random. A preference ratio of less than 1 signifies active avoidance, and a preference ratio of close to 1 indicates a more or less random presence. Differences in the proportion of indigenous and alien street trees with mistletoes, birds, and bird's nests were tested via chi-square tests. Binomial logistic regression was used to determine factors that predict the presence of mistletoes, birds, and nests. The factors included were tree provenance (alien or indigenous), tree circumference, species, street, aspect, and distance to the nearest green space. All data analyses were conducted in Statistica v12. (StatSoft, 213, Tulsa, OK USA).

\section{Results}

A total of 1261 street trees spanning close to 100 species were enumerated, of which almost two-thirds (64.6\%) were alien species. All the three most common species were alien, namely, Jacaranda mimosifolia, Schinus terebinthifolius Raddi, and Fraxinus spp. (Table 1).

Table 1. The five most common alien and indigenous street tree species in Grahamstown $(n=1261)$.

\begin{tabular}{cccc}
\hline Alien & \% of All Trees & Indigenous & \% of All Trees \\
\hline Jacaranda mimosifolia & 8.7 & Erythrina caffra & Celtis africana \\
Schinus terebinthifolius & 8.6 & Acacia karroo & 6.0 \\
Fraxinus spp. & 7.3 & Ekebergia capensis & 5.6 \\
Brachychiton acerfolium & 6.4 & Harpephyllum caffrum & 3.4 \\
Grevillea robusta & 5.9 & Total number of tree species & 3.2 \\
Total number of tree species & 61 & Total proportion (\%) of all street trees & 30 \\
Total proportion (\%) of all street trees & 64.6 & 35.4 & \\
\hline
\end{tabular}

Only one mistletoe species was found: Viscum obscurum Thunb. Across all sampled trees, $7.9 \%$ had mistletoes. Corresponding figures for bird's nests and for birds were $6.2 \%$ and $8.9 \%$, respectively. There were significant differences in the presence rates between indigenous and alien street tree species for mistletoes, birds, and bird' nests (Figure 1). In the case of mistletoes, they were significantly more prevalent in alien tree species than indigenous tree species. For birds and bird's nests, the opposite pattern prevailed, with significantly more indigenous street tree species harbouring them than alien ones.

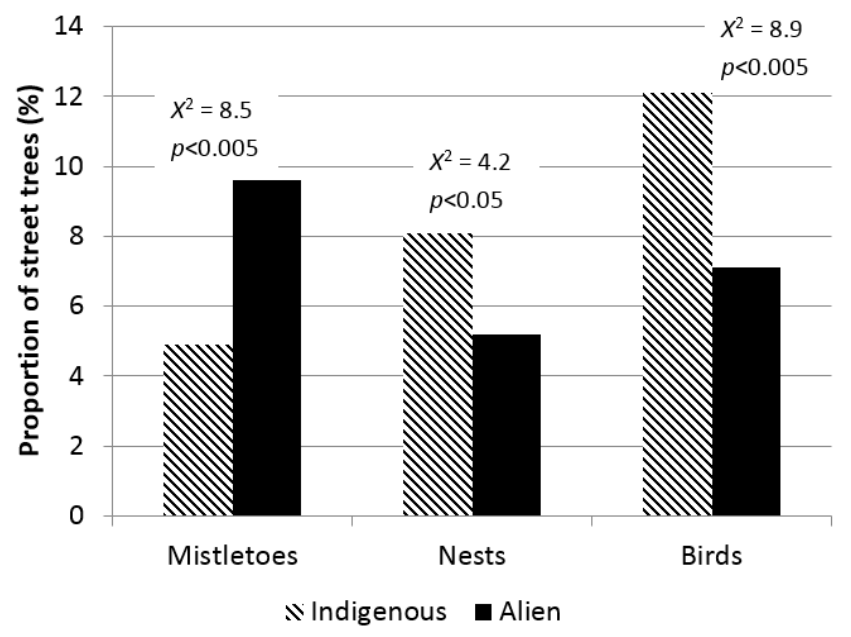

Figure 1. Prevalence (\% of trees) of mistletoes, birds, and bird's nests in indigenous and alien street trees in Grahamstown (chi-square results indicate the significance of the difference in \% of indigenous and alien street trees with each of mistletoes, birds, and nests). 
A greater number of bird species were recorded in indigenous street trees than in alien ones-25 and 18, respectively (Figure 2) - even though there were almost 50\% fewer indigenous street trees. The mean density of birds per tree also significantly favoured indigenous species over alien ones, being almost three times greater (Figure 2). Twenty-nine species of birds were recorded, of which 12 were recorded only in indigenous tree species, 11 were common to both indigenous and alien tree species, and 6 were recorded in alien trees only. The most commonly recorded bird species were the laughing dove (Streptopelia senegalensis L.), the redwing starling (Onychognathus morio L.), the cape weaver (Ploceus capensis L.), the cape white eye (Zosterops virens Sundevall), and the black-capped bulbul (Pycnonotus barbatus Desfontaines).
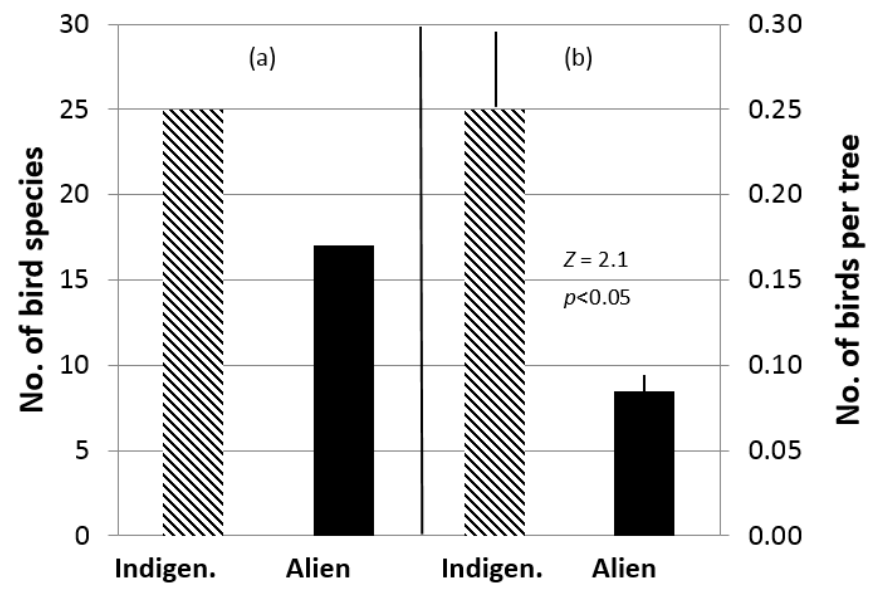

Figure 2. Bird species richness (a) and mean density per tree (b) for indigenous and alien street trees in Grahamstown.

Presence rates were not equal across tree species, with some being strongly favoured and some largely avoided. Of the 15 most abundant street tree species, Acacia karroo Hayne was favoured for birds and nests, with mistletoe infection being approximately proportional to $A$. karroo representation in the tree sample (Table 2). None of the common indigenous street tree species were avoided by birds. Most of the more common alien tree species had low PRs for mistletoes, birds, and nests, except Fraxinus spp., for which the PR was high for mistletoes and birds, and Quercus robur L., which had high PRs for nests and birds.

Table 2. Preference ratios of mistletoes, birds and bird's nests for the 15 most common street trees in Grahamstown (PR of close to 1 indicates more or less random occurrence in street tree species; $>1$ indicates positive association with the tree species; PR of $<1$ signifies under-representation or avoidance of that tree species).

\begin{tabular}{cccccc}
\hline Species & Origin & No. Sampled & Mistletoes & Nests & Birds \\
\hline Acacia karroo & Indig & 63 & 0.8 & 3.2 & 2.1 \\
Celtis africana & Indig & 70 & 0.2 & 1.9 & 1.0 \\
Ekebergia capensis & Indig & 43 & 0 & 0.4 & 2.1 \\
Erythrina caffra & Indig & 76 & 0 & 0.4 & 1.9 \\
Harpephyllum caffrum & Indig & 40 & 0 & 0 & 1.1 \\
Podocarpus falcatus & Indig & 34 & 0 & 0.5 & 1.3 \\
Brachychiton acerfolium & Alien & 81 & 0 & 0.2 & 0.4 \\
Brachychiton populneum & Alien & 24 & 0.5 & 0.7 & 0.5 \\
Eucalyptus ficifolia & Alien & 40 & 0 & 0 & 0.3 \\
Fraxinus sp & Alien & 92 & 0.4 & 1.9 & 0.4 \\
Grevillea robusta & Alien & 74 & 0.1 & 0.9 & 1.2 \\
Jacaranda mimosifolia & Alien & 110 & 0.3 & 0.3 & 0.7 \\
Quercus robur & Alien & 91 & 0 & 0.8 & 1.5 \\
Schinus terebenthifolius & Alien & 109 & 0 & 0 & 0.8 \\
Tipua tipu & Alien & 17 & & 0.7 \\
\hline
\end{tabular}


Considered against all factors measured, the origin of the tree as either indigenous or alien was the most significant predictor of the presence or absence of mistletoes, birds, and nests (Table 3). However, it was not the only one. Proximity to the nearest green space was also positively related with all three-most for mistletoes and least for nests. Overall, the presence of mistletoes was significantly related to distance, origin, species, and aspect. For the latter, north-facing aspects were relatively devoid of mistletoes. Birds were significantly associated with large indigenous trees and proximity to green spaces, whilst nests were associated with only indigenous trees and proximity.

Table 3. Significant predictors of the presence of mistletoes, birds, and nests in street trees in Grahamstown ( $p$ values; .s = not siginficant).

\begin{tabular}{cccc}
\hline Attribute & Mistletoes & Nests & Birds \\
\hline Street & n.s & n.s & n.s \\
Distance to nearest green area & 0.00002 & 0.0023 & 0.0116 \\
Aspect & 0.0257 & n.s & n.s \\
Tree species & 0.0048 & n.s & n.s \\
Origin & 0.0003 & 0.0361 & 0.0016 \\
Tree circumference & n.s & n.s & 0.00001 \\
\hline
\end{tabular}

At a larger spatial scale, a positive relationship $\left(r^{2}=0.304 ; p<0.0005\right)$ was evident between bird species richness per street and trees species richness per street (Figure 3); thus, more trees species in a street resulted in more bird species. Bird species richness per street was also positively associated with tree density per street, albeit only weakly $\left(r^{2}=0.11 ; p<0.05\right)$.

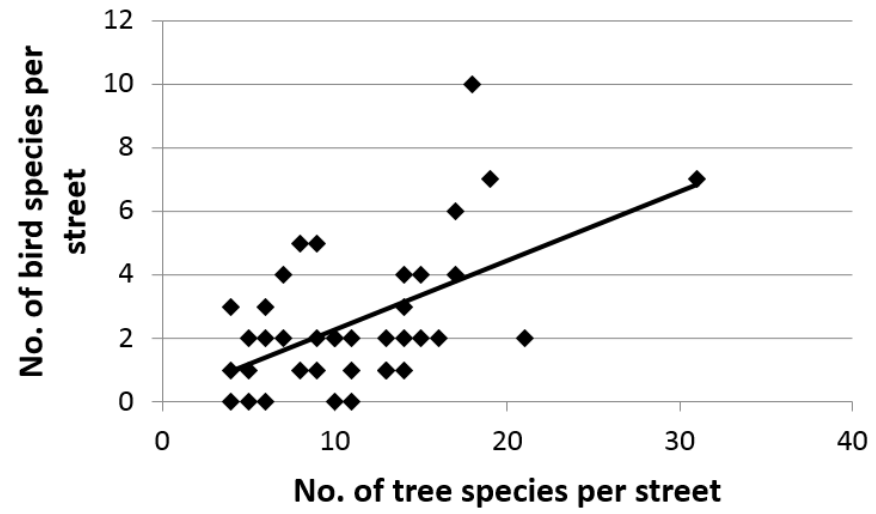

Figure 3. Bird species richness per street as a function of tree species richness per street $\left(r^{2}=0.304\right.$; $p<0.0005)$.

\section{Discussion}

With respect to the research objective, the results are contradictory between the two taxonomic groups investigated, with bird richness, abundance, and breeding (indicated by nests) favoured by native street trees and mistletoes by alien street trees. The findings regarding birds tend to support previous studies, in that some bird species favour indigenous woody plants, whilst others are influenced more by density and structure of the vegetation than the provenance of the woody plant species. Nonetheless, the seminal study by Ikin et al. [26] illustrated markedly higher bird species richness and abundance in native tree species than exotic ones, irrespective of structure, in Canberra, Australia. For insectivorous birds, this may be a consequence of the higher abundance and richness of arthropods on indigenous trees than exotic ones as reported by Bhullar \& Majer [27] in contrasting two indigenous and two exotic trees species. Chong et al. [14] showed higher beta diversity for birds across parks dominated by indigenous flora relative to those with exotic flora.

Most previous work in this debate has been on fauna, with limited consideration of flora [11] such as mistletoes and understorey flora; hence, there is limited opportunity for comparative analysis 
of the results. Mistletoes are important as they attract frugivorous birds which, in turn, disperse the mistletoe seeds as well as seeds of other fruiting plants [28]. Gairola et al. [15] reported mistletoes on 30 tree species in urban parks in Durban (South Africa), of which 16 were alien species. The alien tree species, Melia azedarach L., had the highest infestation rate. In Singapore, Izuddin \& Webb [29] found 3937 epiphytes spanning 51 species in 1170 Albizia saman F.Muell. street trees. My results corroborate theirs in that tree size and proximity to green patches were positively related to epiphyte presence and richness.

The results show that the presence of birds was higher in large trees than in small ones, mirroring the findings from other settings [6,30,31]. This may be an active selection for large trees or may simply be a reflection of the size effect (larger trees have a larger volume and therefore a greater random likelihood of harbouring a bird). Nonetheless, it does show the importance of ensuring that there is a range of tree sizes available in the urban forest. The need for a diversity of trees sizes has recently been emphasised [32] because of the increasing tendency for city authorities to plant small statured species because they are cheaper and easier to manage and require less space when mature [33]. However, large trees do not only provide greater canopy volume, but also a greater diversity of habitats as they age [32]. For example, they typically contain more hollows [12], and both fungal density [34] and lichen prevalence [35] are higher in larger trees than smaller ones. Whilst my results did not show a relationship between tree size and the presence of mistletoes, Gairola et al.'s [15] did, with larger trees having more.

The positive relationship between the presence of mistletoes, birds, and nests in street trees and proximity to the nearest green space reveals the importance of connectivity. Whilst the abundance of street trees in the western section of Grahamstown is high [23], it is highly probable that not all resource needs are met from the street trees only, but that birds disperse laterally into private gardens and broader patches of formal and informal green space. Since mistletoes are bird-dispersed, they are likely to follow a similar pattern. Connectivity is important for a variety of organisms in human-transformed landscapes such as urban areas and agricultural lands [36,37]. These results suggest the importance of street trees in facilitating movement between urban green spaces. This is further emphasised through the positive relationship between street tree richness at the street scale and of bird species richness at the same scale.

This work corroborates previous conclusions $[10,11]$ that alien tree species can provide ecosystem services in support of other biodiversity because mistletoes, birds, and nests were found in alien as well as indigenous street trees. However, from a conservation perspective, this conclusion is insufficient. As argued earlier, the question should not be whether alien tree species can provide the same services and support to other biodiversity as native species, but whether they support a greater suite of species or abundance of native flora and fauna for the same unit of abundance (such as canopy volume). If they do not, then there is no reason against favouring indigenous species from a conservation point of view. The preference ratios indicate strong associations of birds for a number of native street trees, but very few alien ones, which suggests that were there no alien street trees in the study area, there would probably be little negative effect on the richness of avifauna in the city. On the other hand, the abundance of mistletoes would likely be greatly reduced if there were fewer or no alien street trees. However, they would not be absent, as mistletoes were also recorded in indigenous street trees-most notably, Acacia karroo. The choice of whether to favour birds or mistletoes in selecting trees to plant is a value judgement. However, birds are inspiring organisms for many urban residents, and there are many different bird species making use of the street trees. In contrast, mistletoes do not instil such similar levels of respect and enjoyment, and, in Grahamstown, only one species was encountered. Moreover, heavy infections of mistletoes can result in branch loss, which adds to tree maintenance costs. However, epiphytes such as mistletoes can be important in providing habitat to invertebrate fauna [29], which requires investigation in South Africa. 


\section{Conclusions}

In conclusion, this study has shown that native street trees show higher species richness and density of birds than do non-native street trees and that birds display a positive preference for several native tree species, but only one alien tree species. In contrast, mistletoe prevalence was markedly higher for alien tree species, notably Fraxinus sp., than for indigenous tree species, but they were still found in native tree species. Overall, the results indicate that a policy of promoting the planting of only indigenous street trees is likely to favour birds without unduly effecting mistletoes.

Acknowledgments: This work was sponsored by the South African Research Chairs Initiative of the Department of Science and Technology and the National Research Foundation of South Africa. Any opinion, finding, conclusion, or recommendation expressed in this material is that of the author, and the NRF does not accept any liability in this regard.

Conflicts of Interest: The author declares no conflict of interest. The founding sponsors had no role in the design of the study; in the collection, analyses, or interpretation of data; in the writing of the manuscript; or in the decision to publish the results.

\section{References}

1. Niemelä, J.; Saarela, S.-R.; Söderman, T.; Kopperoinen, L.; Yli-Pelkonen, V.; Väre, S.; Kotze, D.J. Using the ecosystem services approach for better planning and conservation of urban green spaces: A Finland case study. Biodiv. Conserv. 2010, 19, 3225-3243. [CrossRef]

2. Roy, S.; Byrne, J.; Pickering, C. A systematic quantitative review of urban tree benefits, costs, and assessment methods across cities in different climatic zones. Urban For. Urban Green. 2012, 11, 351-363. [CrossRef]

3. Livesley, S.J.; McPherson, G.M.; Calfapietra, C. The urban forest and ecosystem services: Impacts on urban water, heat and pollution cycles at the tree, street and city scale. J. Environ. Qual. 2016, 45, 119-124. [CrossRef] [PubMed]

4. Todorova, A.; Asakawa, S.; Aikoh, T. Preferences for and attitudes towards street flowers and trees in Sapporo, Japan. Landsc. Urban Plan. 2004, 69, 403-416. [CrossRef]

5. Antupit, S.; Gray, B.; Woods, S. Steps ahead: Making streets that work in Seattle, Washington. Landsc. Urban Plan. 1996, 35, 107-122. [CrossRef]

6. Tzilkowski, W.M.; Wakeley, J.S.; Morris, L.J. Relative use of municipal street trees by birds during summer in state college, Pennsylvania. Urban Ecol. 1986, 9, 387-398. [CrossRef]

7. Kubista, C.E.; Bruckner, A. Importance of urban trees and building as daytime roost for bats. Biologia 2015, 70, 1545-1552. [CrossRef]

8. Kendle, A.D.; Rose, J.E. The aliens have landed! What are the justifications for 'native only' policies in landscape plantings? Landsc. Urban Plan. 2000, 47, 19-31. [CrossRef]

9. Smith, R.M.; Thompson, K.; Hodgson, J.G.; Warren, P.H.; Gaston, K.J. Urban domestic gardens (IX): Composition and richness of the vascular plant flora, and implications for native biodiversity. Biol. Conserv. 2006, 129, 312-322. [CrossRef]

10. Johnston, M.; Nail, S.; James, S. 'Natives versus aliens': The relevance of the debate to urban forest management in Britain. In Trees, People and the Built Environment, Proceedings of the Urban Trees Research Conference, Birmingham, UK, 13-14 April 2012; Johnston, M., Percival, G., Eds.; pp. 181-191.

11. Chalker-Scott, L. Nonnative, noninvasive woody species can enhance landscape biodiversity. Arboric. Urban For. 2015, 41, 173-186.

12. Carthew, S.M.; Yáñez, B-M.; Ruykys, L. Straddling the divide: Den use by brushtail possums (Trichosurus vulpecula) in urban parklands. Urban Ecosyst. 2015, 18, 525-538. [CrossRef]

13. Blanchon, D.; Pusateri, J.; Galbraith, M.; Thorpe, S. Sampling indigenous ground-living beetles in a stand of non-native tree privet (Ligustrum lucidum) in New Zealand raises new management questions. Ecol. Manag. Restor. 2011, 12, 234-236. [CrossRef]

14. Chong, K.Y.; Teo, S.; Kurukulasuriya, B.; Chung, Y.F.; Rajathurai, S.; Tan, H.T.W. Not all green is as good: Different effects of the natural and cultivated components of urban vegetation on bird and butterfly diversity. Biol. Conserv. 2014, 171, 299-309. [CrossRef] 
15. Gairola, S.; Bhatt, A.; Govender, Y.; Baijnath, H.; Porcheş, S.; Ramdhani, S. Incidence and intensity of tree infestation by the mistletoe Erianthemum dregei (Eckl. \& Zeyh.) V. Tieghem in Durban, South Africa. Urban For. Urban Green. 2013, 12, 315-322.

16. French, K.; Major, R.; Hely, K. Use of native and exotic garden plants by suburban nectarivorous birds. Biol. Conserv. 2005, 121, 545-559. [CrossRef]

17. Gray, E.R.; van Heezik, Y. Exotic trees can sustain native birds in urban woodlands. Urban Ecosyst. 2015. [CrossRef]

18. Dickie, I.A.; Bennett, B.M.; Burrows, L.E.; Nunez, M.A.; Peltzer, D.A.; Porté, A.; Richardson, D.M.; Rejmánek, M.; Rundel, P.W.; van Wilgen, B.W. Conflicting values: Ecosystem services and invasive tree management. Biol. Invasions 2014, 16, 705-719. [CrossRef]

19. Climatedata.eu. Available online: http://www.climatedata.eu/climate.php?loc=sfzz0020\&lang=en (accessed on 13 March 2013).

20. State of the Environment South Africa, 2007. Available online: http://soer.deat.gov.za/332.htm (accessed on 15 March 2015).

21. Mucina, L.; Rutherford, M.C. The Vegetation of South Africa, Lesotho and Swaziland. Strelitzia 19; South African National Biodiversity Institute (SANBI): Pretoria, South Africa, 2006; p. 816.

22. McConnachie, M.M.; Shackleton, C.M. Public green space inequality in small towns in South Africa. Habit. Int. 2010, 34, 244-248. [CrossRef]

23. Kuruneri-Chitepo, C.; Shackleton, C.M. The distribution, abundance and composition of street trees in selected towns of the Eastern Cape, South Africa. Urban For. Urban Green. 2011, 10, 247-254. [CrossRef]

24. Gwedla, N.; Shackleton, C.M. The development visions and attitudes towards urban forestry of officials responsible for greening in South African towns. Land Use Policy 2015, 42, 17-26. [CrossRef]

25. Richardson, E.; Shackleton, C.M. The extent, causes and local perceptions of street tree damage in small towns in the Eastern Cape, South Africa. Urban For. Urban Green. 2014, 13, 425-432. [CrossRef]

26. Ikin, K.; Knight, E.; Lindenmayer, D.B.; Fischer, J.; Manning, A.D. The influence of native versus exotic streetscape vegetation on the spatial distribution of birds in suburbs and reserves. Divers. Distrib. 2013, 19, 294-306. [CrossRef]

27. Bhullar, S.; Majer, J. Arthropods on street trees: A food resource for wildlife. Pac. Conserv. Biol. 2000, 6, 171-173. [CrossRef]

28. Watson, D.M. The relative contribution of specialists and generalists to mistletoe dispersal: Insights from a neotropical rain forest. Biotropica 2013, 45, 195-202. [CrossRef]

29. Izuddin, M.; Webb, E.L. The influence of tree architecture, forest remnants, and dispersal syndrome on roadside epiphyte diversity in a highly urbanized tropical environment. Biodivers. Conserv. 2015, 24, 2063-2077. [CrossRef]

30. Palomino, D.; Carrascal, L.M. Birds on novel island environments: A case study with the urban avifauna of Tenerife (Canary Islands). Ecol. Res. 2005, 20, 611-617. [CrossRef]

31. MacGregor-Fors, I. Relation between habitat attributes and bird species richness in western Mexico suburbs. Landsc. Urban Plan. 2008, 84, 92-08. [CrossRef]

32. Stagoll, K.; Lindenmayer, D.B.; Knight, E.; Fischer, J.; Manning, A.D. Large trees are keystone structures in urban parks. Conserv. Lett. 2012, 5, 115-122. [CrossRef]

33. Nagendra, H.; Gopal, D. Tree diversity, distribution, history and change in urban parks: Studies in Bangalore, India. Urban Ecosyst. 2011, 14, 211-223. [CrossRef]

34. Heilmann-Clausen, J.; Christensen, M. Does size matter? On the importance of various dead wood fractions for fungal diversity in Danish beech forests. For. Ecol. Manag. 2004, 201, 105-117. [CrossRef]

35. Johansson, P.; Erlén, J. Influence of habitat quantity, quality and isolation on the distribution and abundance of two epiphytic lichens. J. Ecol. 2003, 91, 213-221.

36. Vergnes, A.; Le Viol, I.; Clergeau, P. Green corridors in urban landscapes affect the arthropod communities of domestic gardens. Biol. Conserv. 2012, 145, 171-178. [CrossRef]

37. Braaker, S.; Ghazoul, J.; Obrist, M.K.; Moretti, M. Habitat connectivity shapes urban arthropod communities: The key role of green roofs. Ecology 2014, 95, 1010-1021. [CrossRef] [PubMed]

(C) 2016 by the author; licensee MDPI, Basel, Switzerland. This article is an open access article distributed under the terms and conditions of the Creative Commons Attribution (CC-BY) license (http:/ / creativecommons.org/licenses/by/4.0/). 